\title{
CONFERENCE REPORT: 1ST INTERNATIONAL CONFERENCE OF THE CENTRAL EUROPEAN NETWORK OF LEGAL SCHOLARS (CENELS) ON "25 YEARS AFTER THE TRANSFORMATION: LAW AND LEGAL CULTURE IN CENTRAL AND EASTERN EUROPE. BETWEEN CONTINUITY AND DISCONTINUITY", MASARYK UNIVERSITY, BRNO, CZECH REPUbliC, 16- 17 APRIL 2015
}

\author{
WOJCIECH ZOMERSKI*
}

On 16-17 April 2015, Masaryk University (Brno, Czech Republic), in cooperation with the University of Social Sciences and Humanities, Faculty in Wrocław (Poland), hosted the 1st Annual International Conference of the Central European Network of Legal Scholars (CENELS) devoted to the topic of " 25 Years After the Transformation: Law and Legal Culture in Central and Eastern Europe. Between Continuity and Discontinuity". The Organising Committee of the conference was composed of Doc JUDr Mgr Martin Škop, $\mathrm{PhD}$, Doc JUDr Radim Polčák, Mgr Markéta Klusoňová (all from Masaryk University), Prof Dr hab. Leszek Koczanowicz (University of Social Sciences and Humanities, Faculty in Wrocław) and Dr Rafał Mańko (University of Amsterdam, Centre for the Study of European Contract Law), who was responsible for the conference programme. The conference inaugurated the activity of the Central European Network of Legal Scholars (CENELS), an informal network of academic lawyers working on Central European law from universities within the region or abroad. As Dr Mańko, the coordinator of CENELS, explained at the conference, the idea of the meeting is to create an informal platform for the exchange of research ideas and information about

\footnotetext{
DOI: $10.1515 /$ wrlae-2015-0017

* Master's student of law, Unviersity of Wrocław.
} 
conferences, workshops as well as funding opportunities. In the future, it is possible that CENELS would become formalised.

In line with its title, the 1st Annual Conference of CENELS focused on "25 Years After the Transformation", taking stock of the recent anniversary of the demise of Actually Existing Socialism (1989/1990). The focus of the conference was not only on the modification of legal rules, but also on the adaptation of legal cultures, including judicial mentalities. The innovative aspect of the conference was that it considered the process of postcommunist transformation as an ongoing and unfinished process. Central Europe, despite the passage of 25 years from the fall of Actually Existing Socialism, continues to be a different space on the legal map of Europe from Western Europe or Southern Europe.

From a methodological standpoint, the conference focused on the socio-legal aspects of the transformation. As the organisers pointed out in the call for papers, whilst some areas, such as lustration and transitional justice, have already been thoroughly researched, the main aim of the conference was to focus on generally neglected topics such as "legal survivals" of the socialist period. Another area of interest concerned the subject of continuity or discontinuity in legal culture in regard to such dimensions as the attitudes of judges and scholars to legal interpretation or generally held views on the place of law in society. As the organisers put it, the main aim was "to invite a broad outlook upon the socio-legal aspects of transformation, including the role of law in the transformation of social consciousness, the construction of collective identities and the framing of social dialogue". During the conference the participants agreed that the first gathering of CENELS had brought a fresh perspective on legal discourse in Central Europe, as the papers indicated that the transformation was not merely a single event which occurred in the past, but is rather a process that is still ongoing and determines the actions of legal institutions and legal thinking.

The opening session took place on 16 April in the building of Faculty of Law of Masaryk University. On behalf of the organising committee, Professor Martin Škop enthusiastically welcomed the gathering of legal scholars from Central and Eastern Europe. Speaking on behalf of the Faculty, Dean Markéta Selucká also welcomed the audience and stressed the importance of scholarly cooperation in the region. The first plenary session, chaired by Professor Martin Škop, was opened by Professor Adam Czarnota (University of New South Wales, Sydney, Australia; Oñati International Institute for the Sociology of Law, Spain; University of Białystok, Poland) who spoke about Law and society after communism. An attempt of assessment. Professor Czarnota focused on showing the hidden dimension of the operation of formal law in post-communist social systems. He also attempted to build a contemporary portrait of law and society, including legal education 25 years after the collapse of communism. Professor Czarnota's conclusion was that the aftermath of communism within legal culture is still present and has not disappeared despite the passage of a quarter of a century. The second speaker, Professor Leszek Koczanowicz, delivered a paper entitled Hopes and Disappointment. Transformation after 25 years. Professor Koczanowicz, whilst participating in the production of ARTE documentary 
"Children of Revolution", visited the former communist states including Poland, East Germany, Czech Republic and Hungary and discovered that the majority of the each society was disappointed with the outcomes of transformation. People from this region had expected a more ethical politics and their disappointment was caused by the political reality, which they largely found to be corrupt. Therefore, in his paper, Professor Koczanowicz intended to compare the hopes and expectations at the beginnings of transformation with the social and political reality of 2015 . He also attempted to answer what should be a measuring stick of transformation: the ethical shape of society, social justice and the level of democratisation or perhaps economic success? The speaker also introduced the notion of "post-postcommunism" in order to indicate the phase of development in which the Central European region finds itself now.

The plenary session was followed by two parallel sessions. The session entitled Public Law I: Transitional Justice, chaired by Professor Adam Czarnota, was opened by Dr Aleksandra Gliszczyńska-Grabias (Poznań Human Rights Centre) who spoke about Victimhood of the Nation as a Legally Protected Value in Transitional States - Poland as a Case-Study. The second paper, delivered by Mgr Filip Cyuńczyk (University of Białystok \& International Institute for the Sociology of Law in Oñati), was called Do we need legal petrification of the past? Motives for adoption of statuses establishing the institutes of national remembrance. The last speaker, Mgr Anna Rocławska (University of Silesia), delivered a paper entitled $A$ judge with 'unblemished character' - the question about the banality of evil in Polish justice system before and after political transformation. The Private Law I session was chaired by Dr Aleksandra Kustra (Nicolaus Copernicus University in Torun, Poland \& Constitutional Court of the Republic of Poland) and was opened by Dr Rafał Mańko, who spoke about Polish Private Law 25 Years After the Transformation: Between Continuity and Discontinuity. The second speaker, Dr Libor Kyncl (Masaryk University) delivered a paper entitled Privatization, Continuity and Transformation of State Capital Participation. The last paper, delivered by Mgr Michał Stambulski (Centre for Legal Education and Social Theory), was devoted to The Fantasy of Transformation: Ideas of free market and the property rights in the time of transition in Poland.

The second plenary session was chaired by Dr Rafał Mańko. The first speaker, Professor Zdeněk Kühn (Associate Professor at Charles University and Judge at the Supreme Administrative Court of the Czech Republic) delivered a paper concerning Conceptions of law and their non/transformation after 1989. Professor Kühn focused on the continuity of the narrow and reductionist concept of law in judicial mentality. The second paper, delivered by Professor Matej Avbejl (Dean of the Graduate School of Governance and European Studies, Kranj, Slovenia), was devoted to Undoing the Remnants of the Deeply Illiberal Past in the Judiciary in a Constitutional 
Way - the Case of Slovenia. Professor Avbejl argued that the obstacle preventing the full transformation of Slovenia lies in a judiciary that has never been subject to lustration and, therefore, remains part of the old totalitarian nomenclature. In his paper, he also attempted to answer the question "how can a de facto illiberal country be constitutionally turned into a de facto liberal constitutional democracy, in which its institutional actors, in particular judges, will truly internalize and therefore live up to the declared constitutional standards?".

The plenary session was followed by another two parallel sessions. The session called Public Law II, chaired by Dr Rafał Mańko, was opened by Dr Aleksandra Kustra, who spoke about The role of the Polish Constitutional Tribunal in legal transformation in Poland after 1989. The second paper, delivered by Dr Hanna Dębska and Dr Tomasz Warczok (Pedagogical University in Kraków \& Institute for Social Studies at the University of Warsaw), concerned Legitimacy in Narration: Communism and Democracy as Mythical Codes in the Discourse of the Polish Constitutional Tribunal. The third speaker, Mgr Konrad Kobyliński (University of Silesia, Katowice, Poland), spoke about Decisions of the Polish Constitutional Tribunal after 25 years of transformation from the attitudinal perspective? The final paper within this session was delivered by Wojciech Zomerski (University of Wrocław) and was devoted to What happens when a homophobe interprets constitutional provisions? Reconstruction of debate on Article 18 of the Polish Constitution. The session entitled Procedural Law and the Judiciary was chaired by Dr Krisztina Ficsor (University of Debrecen). The first speaker, Prof Dr hab. Agnieszka Skóra (University of Warmia and Mazury, Olsztyn, Poland) spoke about State and Legal Authority: the 'Manager of the Proceedings' or 'Sponsor to the Party'? The shift in the party's status in general administrative proceedings over the last 25 years. The second paper, delivered by Dr Jan Winczorek (University of Warsaw), was devoted to Adversarial or inquisitorial? Effectiveness of reforms of Polish civil procedure. The third speaker, Dr Mátyás Bencze (University of Debrecen), discussed Presumption of guilt in Hungary - a Socialist heritage? The last paper was delivered by Dr Patrik Rako, LLM (Paneuropean University), and Dr Marta Dercova Holevova and was called Not in the Public Interest.

The second day of the Conference was opened by two parallel sessions. The session Public Law III was chaired by Dr Mátyás Bencze. The first speaker, Prof Dr Sergey Korolev (Russian Academy of Sciences Moscow, Russia) spoke about On the Modified One-Party Rule in the 'Residue States' of the Dismembered USSR. The second paper was delivered by Doc Dr Jānis Pleps (Rīga) and concerned The continuity of the constitutions in the Baltic states. The third speaker, Dr Ágnes Kovács (University of Debrecen), delivered a paper entitled The Role of the Hungarian Parliament in Political Decision Making after the Democratic Transition - Continuity or Discontinuity. The session Private Law II, chaired by Mgr Markéta Klusoňovà, was opened by Professor Daiva Petrylaitè (Vilnius University) who spoke about The institute of social partnership in 'post-Soviet' society: challenge for trade unions identifying the new tasks in nowadays labour market conditions. The second speaker, Dr Katarzyna 
Bomba (University of Warmia and Mazury), delivered a paper concerning Union solidarity in Eastern and Central Europe on the example of Poland. The final paper within this session was delivered by Dr Piotr Fiedorczyk (University of Białystok) and concerned Polish Family Law: Socialist Roots, Astonishing Evolution.

Shortly afterwards, another two parallel sessions took place. The session Public Law IV was chaired by Dr Mátyás Bencze. The first speaker, Dr Zdeněk Nový, LLM (Masaryk University) delivered a paper entitled State Succession into Debts: a Revival of Odious Debt Doctrine? The second paper, delivered by Mgr Piotr Eckhardt (Jagiellonian University), concerned Spatial planning law and the political transformation: New challenges - sufficient reforms? The last speaker, Mgr Marcin Wróbel (Jagiellonian University), spoke about (Lack of) transformation. Legal protection of the natural environment in Poland. The session Legal Theory I, chaired by Professor Zdeněk Kühn, was opened by Dr Krisztina Ficsor, who spoke about: The Limits of Judicial Formalism in Criminal Cases. The second paper, delivered by Mgr Markéta Klusoňovà, was devoted to Matter of Style (of Judicial Decisions). The session was finished by Mgr Kuba Gąsiorowski (Jagiellonian University), who delivered a paper entitled The institution of principles of social coexistence in laws of former Eastern Bloc countries - an effective counterpart of principle of good faith or an obsolete ideological remnant of socialism?

The third plenary session was chaired by Professor Leszek Koczanowicz. Professor Adam Sulikowski (University of Wrocław and University of Opole) spoke about The Polish Constitutional Court as a Guardian of Collective Hypocrysy. Professor Sulikowski considered, deploying Bourdieu's concept derived from famous essay entitled Les jursites-gardiens de l'hypocrisie collective, the role of the Polish Constitutional Court as a guardian of collective hypocrisy. As Professor Sulikowski put it, in Poland there is a historically entrenched division between the "noble nation" and "dark people". In consequence, the raison d'état has been usually identified with the presumed will of the nobility. The PCC "invented' in the 1970s, in turn, until today embodies the interests of the "moderate nobility", and therefore its main purpose is the juridification and neutralisation of the political and economic agenda of the "moderate nobility".

The plenary session was followed by another two parallel sessions. The session Public Law V was chaired by Professor Sergey Korolev. The first paper was delivered by Dr Ewa Wójcicka (Jan Długosz Academy in Częstochowa, Poland) and concerned The right of petition in the Republic of Poland - new challenges and new solutions. The second speaker, Mgr Monika Stachoňová (Masaryk University), spoke about (Dis) continuity of the Media Law in the Czech Republic, particularly with regard to state interventions and the application of human rights in the media. The third 
paper, delivered by Mgr Daria Wójcik (Jagiellonian University), was devoted to Policing in Poland 25 Years after the Transformation. The final paper was delivered by Mgr Anna Wójcik (Editor of Res Publica Nowa) and was entitled Are the gallerists more severe than judges? The scope of the freedom of artistic expression in Poland after 1989. The session Legal Theory II, chaired by Doc Dr Jānis Pleps, was opened by Dr Paulina Święcicka (Jagiellonian University) who spoke about The Demythologised Code: The Code - a metaphor we - the contemporary jurists - live by. The second speaker, Dr Paweł Skuczyński (University of Warsaw), delivered a paper concerning Lawyers' Ethics in Poland Before and After 1989. The final paper was delivered by Maciej Krogel (University of Wrocław) and concerned Repatriation as decision of a post-transformation sovereign.

The academic proceedings of the conference were followed by a concluding session. Professor Martin Škop thanked scholars for a fruitful conference and hoped that it would be the beginning of a new movement of scholars in Central and Eastern Europe. In response to this, Professor Matej Avbelj and Dr Rafał Mańko presented their vision for the future development of CENELS. They underlined the need to supplement existing centreperiphery relationships (i.e. multilateral academic cooperation between Central European countries and Western Europe) with intra-Central European cooperation, which can certainly be fostered through the informal CENELS platform.

The 2nd Annual CENELS conference is due to be held in Ljubljana (Slovenia) in June 2016, and will be hosted by the Društvo Evropska Slovenija (Association for a European Slovenia). The Organising Committee will be headed by Doc Dr Matej Avbelj, President of the association and Dean of the Graduate School of European Studies in Kranj. The topic of the conference will be devoted to "Central Europe as a Legal Space: What do we share? What divides us? What can we do legally in common?" It is expected that this gathering will lead to the formalisation of CENELS as an interuniversity platform of academic cooperation in the region. 